\title{
Pendidikan dan Modernisasi
}

\author{
Anggelika Permata Sari, Cahaya Melynia, Harun Ar Rasyid Lim Seong Been \\ Program Studi Pendidikan Sejarah Fakultas Keguruan dan Ilmu Pendidikan \\ Universitas Lambung Mangkurat \\ Banjarmasin
}

\begin{abstract}
Abstrak
Pendidikan merupakan usaha pengembangan kualitas diri manusia dalam segala aspek. Modernisasi adalah proses perubahan individu-individu dari cara hidup tradisional menuju kehidupan yang lebih kompleks, menuju kemajuan teknologi dan merupakan perubahan cara hidup yang cepat. Pendidikan merupakan ikhtiar ke dalam diri manusia dan modernisasi merupakan ikhtiar ke luar diri manusia, dalam rangka mencapai kehidupan yang baik bagi manusia itu sendiri. Dalam menuju proses modernisasi pendidikan perlunya pendidikan karakter didalamnya agar menunjang pembentukan karakter yang baik pada diri manusia agar bisa mengembangkan kemajuan teknologi dengan baik pula. Modernisasi hanya dapat dicapai dengan memperbaharui dan meluaskan pendidikan. Dalam proses modernisasi, pendidikan memegang peranan cukup besar. Melalui pendidikan diharapkan pengembangan pengetahuan keterampilan dan nilai-nilai serta sikap-sikap yang dibutuhkan dalam proses modernisasi dapat ditransformasikan secara meluas di kalangan masyarakat baik melalui pendidikan formal informal maupun nonformal.
\end{abstract}

\section{PENDAHULUAN}

Kata "pendidikan" dalam Bahasa Inggris sepadan dengan kata "Education" yang secara etimologi diserap dari Bahasa Latin “Eductum”. Kata Eductum sendiri terdiri dari dua kata yaitu $E$ yang bermakna perkembangan dari dalam keluar atau dari sedikit ke banyak, dan Duco yang bermakna sedang berkembang. Sehingga secara etimologis pendidikan adalah proses pengembangan dalam diri individu. Hal ini sejalan dengan pendapat Priatna (2004:27) bahwa pendidikan merupakan usaha pengembangan kualitas diri manusia dalam segala aspek (Mulyadi \& Haura, 2019: 2). 
Kemudian pendidikan secara luas diartikan juga sebagai proses perubahan sikap dan tingkah laku seseorang atau kelompok orang dalam usaha mendewasakan manusia melalui upaya pengajaran dan latihan (Poerwadarminta, 1985:702) (Mulyadi \& Haura, 2019: 2).

Dalam pengertian luas, Soyomukti (2015:22) dalam Mulyadi dan Haura (2019: 3) mengatakan bahwa :

"Pendidikan adalah hidup. Pendidikan adalah segala pengalaman belajar yang berlangsung dalam segala lingkungan dan sepanjang hidup. Pendidikan adalah segala situasi hidup yang mempengaruhi pertumbuhan individu. Pendidikan seumur hidup bermakna bahwa pendidikan adalah bagian dari kehidupan sendiri. Pengalaman belajar dapat berlangsung dalam segala lingkungan dan sepanjang hayat"

Maka Dalam arti luas tersebut, pendidikan dianggap sebagai suatu proses yang berkelanjutan di dalam kehidupan. Dengan kata lain pendidikan juga dapat bermakna segala aktivitas pengembangan seseorang di berbagai lingkungan yang berlangsung sepanjang hidupnya dan berhubungan dengan dimensi-dimensi lain. Untuk itulah pendidikan tidak dapat mengabaikan hubungan interaksi manusia dengan aspek lain, seperti relasi manusia dengan manusia, manusia dengan alam dan budayanya, bahkan manusia dengan Tuhannya (Mulyadi \& Haura, 2019: 3).

Disadari maupun tidak disadari pendidikan selalu diarahkan untuk mencapai tujuan tertentu. Dalam arti luas, tujuan pendidikan terkandung dalam setiap pengalaman belajar dan tidak ditentukan oleh pihak luar individu. Tujuan pendidikan adalah pertumbuhan, jumlah tujuan pendidikan tidak terbatas. Tujuan pendidikan sama dengan tujuan hidup (Redja Mudyahardjo, 2001) (Mulyadi \& Haura, 2019: 4).

Menurut Rupert S. Lodge: "In the narrower sense, education becomes, in practice identical with schooling, i.e. formal instruction under controlled conditions" (Mohammad Noor Syam, 1984). Pendapat Lodge tersebut dapat diartikan bahwa dalam arti sempit, pendidikan identik dengan penyekolahan (schooling), yaitu kegiatan pembelajaran maupun pengajaran secara formal di bawah kondisi-kondisi yang terkontrol dengan ciri-ciri tertentu. Maka dalam hal ini pengertian pendidikan terbatas pada kegiatan-kegiatan secara formal di lingkungan tertentu saja (sekolah/universitas) (Mulyadi \& Haura, 2019: 4). 
Dalam pengertian sempit tersebut, pendidikan dibatasi hanya bagi mereka yang berpredikat sebagai siswa atau mahasiswa di suatu sekolah, yang secara legitimasi atau berarti telah terdaftar di suatu institusi pendidikan. Selain itu, pengertian sempit tersebut mengantarkan pendidikan pada lingkungan terbatas, yakni Lembaga pendidikan formal, sekolah atau universitas. Aktivitas pendidikan dilakukan dalam melalui kegiatan pembelajaran (studying), serta pengajaran (instruction) yang terstruktur dan bersifat formal, yang dikondisikan secara sengaja dengan berbagai sarana dan sistem-sistem. Mekanisme proses berkegiatan pendidikan juga dibatasi dalam lingkup kurikulum, pelajaran dan materi apa yang akan diberikan dalam kegiatan pendidikan tersebut (Mulyadi \& Haura, 2019: 4-5).

Dalam pengertian sempit, selain dibatasi predikat dan lingkungan, pendidikan juga terbatas pada dimensi waktu. Dimana terdapat variasi lamanya pendidikan setiap individu dapat bergantung pada kemampuan personal, ekonomi, dan faktor lain. Dengan demikian pendidikan dapat diukur dan ditentukan dalam jangka waktu tertentu. Kemudian, Mudyahardjo (2001) mengatakan bahwa dalam pengertian sempit, tujuan pendidikan terbatas pada pengembangan kemampuankemampuan tertentu dan mempersiapkan peserta didik untuk dapat hidup di masyarakat (Redja Mudyahardjo, 2001) (Mulyadi \& Haura, 2019: 5).

Pada dasarnya setiap masyarakat menginginkan perubahan dari keadaan tertentu kearah yang lebih baik dengan harapan akan tercapai kehidupan yang lebih maju dan makmur. Keinginan akan adanya perubahan itu adalah awal dari suatu proses modernisasi (Matondang, 2019: 189).

Pengertian modernisasi mencakup makna yang sangat luas dan tidak dapat ditentukan secara mutlak. Hal ini ditandai dengan tanggapan dan penekanan modernisasi sesuai dengan kondisi dan kebutuhan yang diinginkan dalam perubahan itu (Matondang, 2019: 189).

Menurut Kamus Umum Bahasa Indonesia susunan W.J.S Poerwadarminta, pengertian modern adalah cara-cara baru atau mutakhir (1998 : 124). Modernisasi ialah proses perubahan masyarakat dan kebudayaan dengan seluruh aspeknya dari yang tradisional ke modern. Pengertian ini memberi gambaran bahwa hal-hal yang lama ditinggalkan, dan beralih ke hal yang baru (Matondang, 2019: 189). 
Menurut Everett M. Rogers modernisasi adalah proses perubahan individu-individu dari cara hidup tradisional menuju kehidupan yang lebih kompleks, menuju kemajuan teknologi dan merupakan perubahan cara hidup yang cepat. Sedangkan Syed Hussein Alatas menyatakan bahwa modernisasi merupakan proses dimana ilmu pengetahuan ilmiah modern yang meliputi seluruh aspek kehidupan manusia diperkenalkan pada seluruh tingkat, dengan tujuan akhir mencapai kehidupan yang lebih baik dan lebih memuaskan (Djazifah, 1991: 58).

Dari pengertian diatas tidak ada pengertian yang sama tentang modernisasi. Namun, berdasarkan dari beberapa pendapat tersebut, secara sederhana modernisasi dapat diartikan sebagai proses perubahan masyarakat dari masyarakat tradisional ke masyarakat modern dalam seluruh aspeknya. Bentuk perubahan dalam pengertian modernisasi adalah perubahan yang terarah (direct change) yang didasarkan pada suatu perencanaan (planned change) yang bisa diistilahkan dengan Social Planning (Matondang, 2019: 189).

Secara historis, moderniasi merupakan proses perubahan yang menuju pada tipe sistem-sistem sosial, ekonomi dan politik yang berkembang di Eropa Barat dan Amerika Utara pada abad ke 17 dan 19 yang kemudian menyebar keseluruh penjuru dunia pada abad ke 19 sampai 20 (Koentjaraningrat, 2001 : 45). Proses modernisasi ini, mau tidak mau, suka tidak suka, harus dihadapi manusia yang ingin maju. Segala konsekuensi yang ada harus ditanggung dan harus dijalani agar modernisasi berjalan lancer (Matondang, 2019: 189).

Manusia sebagai pelaku modernisasi dan sekaligus mengalami perubahan sikap, mental, pengetahuan, keterampilan, dan struktur sosial, demi kemajuan dan kesejahteraan yang lebih baik. Jadi manusia harus memiliki kemampuan dan kemauan untuk melakukan modernisasi dalam kehidupannya (Matondang, 2019: 190).

\section{PERANAN PENDIDIKAN DALAM PROSES MODERNISASI}

Menurut Djazifah, Pendidikan dan Modernisasi memiliki titik temu pada aspek manusianya. Pendidikan menekankan pada aspek aktualisasi modal kemandirian manusia guna memanusiakan dan membudayakan dirinya sendiri maupun lingkungannya.

Sedangakan modernisasi menekankan sumber-sumber yang terdapat dalam khasanah kehidupan manusia guna terpenuhinya kebutuhan hidup manusia itu sendiri. Dengan 
demikian dapat dikatakan bahwa pendidikan merupakan ikhtiar ke dalam diri manusia dan modernisasi merupakan ikhtiar ke luar diri manusia, dalam rangka mencapai kehidupan yang baik bagi manusia itu sendiri (Djazifah, 1991: 61).

Modernisasi sebagai upaya pembangunan di setiap aspek kehidupan masyarakat, mutlak memerlukan keikutsertaan upaya pendidikan untuk menstimulir dan menyertai dalam setiap fase dan proses pembangunan tersebut. Dr. Gooding dalam Djazifah (1991: 61) menyatakan bahwa pada setiap fase dan proses pembangunan tersebut memerlukan adanya civic consciousness dan community responsibility among the people. Selain itu, diperlukan konformitas dan partispasi penuh dari masyarakat terhadap upaya pembangunan.

Penuh atau tidaknya partisipasi masyarakat sebagai di dalam usaha pembangunan dipengaruhi oleh akumulasi pengetahuan, keterampilan, dan sikap-sikap yang dimiliki oleh masyarakat. Dalam hal ini, civic consciousness, community responsibility among the people, konformitas, dan partisipasi masyarakat terhadap pembangunan merupakan bidang tugas pendidikan (Djazifah, 1991: 62).

Proses modernisasi menuntut perubahan dan perkembangan masyarakat secara cepat. Hal tersebut memerlukan penyesuain, pengetahuan, keterampilan, nilai-nilai dan sikap tertentu dari anggota masyarakat. Hal ini menunjukkan pendidikan dalam pembangunan dituntut untuk mengemban tugas yang semakin luas dan kompleks sesuai dengan aneka ragam masalah dan hajat hidup masyarakat (Djazifah, 1991: 63).

Pendidikan yang berisi penambahan pengetahuan, keterampilan, nilai-nilai dan sikap-sikap tertentu, dalam peranannya menunjang proses modernisasi hendaknya diarahkan untuk: (1) menambah konformitas seseorang atau masyarakat terhadap nilainilai, cita-cita, atau program pembangunan; (2) menambah kepekaan seseorang atau suatu masyarakat terhadap tantangan, persoalan, hajat hidup pribadi, lingkungan, dan bangsanya yang senantiasa berubah dan berkembang; (3) menambah kemampuan menyelesaikan tantangan persoalan hidup pribadi maupun masyarakat sesuai dengan keadaan yang dihadapi; (4) mengembangkan sikap-sikap yang cocok untuk tuntutan hidup dan kehidupan masa kini maupun yang akan datang, seperti hemat, sederhana, disiplin, bekerja keras, 
menghargai waktu, berorientasi pada masa depan, mencintai lingkungan sekitar, menghargai perbedaan, menghargai diri sendiri, dan sebagainya (Djafziah, 1991: 63).

\section{PENDIDIKAN KARAKTER DAN SIKAP DARI PENDIDIKAN SEJARAH}

Pendidikan sejarah berhubungan erat dengan pendidikan karakter. Menurut Anis (2014) tujuan pembelajaran yang sebenarnya adalah nation and character building. Pendidikan karakter merupakan pendidikan budi pekerti yang melibatkan aspek pengetahuan (kognitif), perasaan, dan tindakan. Bila dihubungkan antara pendidikan sejarah dengan pendidikan karakter, maka dalam kemampuan berkomunikasi, dan mengembangkan kemampuan mencari, mengolah, mengemas, dan mengkomunikasikan informasi. Melalui para guru sejarah pelajaran sejarah yang mengandung pesan-pesan moral didiskusikan kepada siswa (Anis, 2014: 484).

Kata sejarah berasal dari bahasa Arab asyajara berarti terjadi, syajarah berarti pohon, syajarahan- nasab berarti pohon silsilah; apabila dialihbahasakan ke dalam bahasa Inggris history yang berasal dari bahasa Latin dan Yunani yaitu historia. Dalam bahasa Yunan disebut istoria, sedangkan dalam bahasa Latin disebut histoire. Kata historio ketika dipergunakan oleh para ilmuwan dari Ionia (salah satu provinsi Yunani di Asia Muka), seperti Hecatheus 500 SM. Menggunakannya untuk merujuk hasil penelitian tentang gejala /keadaan alam di kawasan yang sudah dihuni oleh manusia. Kemudian, Herodotus yang dikenal sebagai Bapak Sejarah — karyanya tentang; Perang Parsi menarasikan gejala alam akan tetapi karyanya lebih cenderung menarasikan kombinasi antara geografi dan etnografi sebagai latar belakang tentang Perang Parsi (Anis, 2013: 149).

Dalam mencari arti tentang definisi sejarah pada masa kekinian ada begitu banyak yang dimunculkan oleh para sejarawan. Burckhardt mendefinisikan sejarah sebagai catatan tentang suatu masa yang ditemukan dan dipandang bermanfaat oleh generasi berikutnya. Marc Bloch menyebutkan, bahwa sejarah merupakan ilmu tentang manusia dalam rentang waktu. H.G. Wells berpendapat, bahwa sejarah manusia merupakan sejarah tentang gagasan. E.H. Carr menyatakan, bahwa sejarah merupakan dialog tanpa akhir antara masa sekarang dengan masa lampau. R.G. Collingwod penelitian sejarah merupakan tindakan masa lampau. Menarik juga pandangan dari Richard J.Evan (Syamsuddin,2012:7) yang 
menyatakan, sejarah dapat dilihat sebagai sains... pengetahuan yang terorganisasi diperoleh melalui penelitian sesuai dengan metode, dipresentasikan dan menjadi pokok yang direview oleh pakar mitra (Anis, 2013: 150).

Kuntowijoyo (1995:19), berpendapat, bahwa sejarah berguna secara intrinsik dan ekstrinsik. Secara intrinsik, sejarah berguna sebagai pengetahuan yaitu (1) sejarah sebagai ilmu, (2) sejarah sebagai cara untuk mengetahui masa lampau, (3) Sejarah sebagai pernyataan pendapat dan (4) sejarah sebagai profesi (Anis, 2013: 157).

Secara ekstrinsik, sejarah dapat digunakan sebagai liberal education untuk mahasiswa, yaitu; (1) moral; (2) penalaran; (3) politik; (4) kebijaksanaan; (5) perubahan; (6) masa depan; (7) keindahan dan (8) ilmu bantu. Selain sebagai pendidikan, sejarah berfungsi sebagai (9) latar belakang; (10) rujukan dan (11) bukti (Anis, 2013: 157).

Guna sejarah seperti yang dikemukakan Kuntowijoyo akan menjadi komprehensip apabila disandingkan dengan pendapat S.K Kochhar tentang sasaran, tujuan dan nilai sejarah. Singkatnya, sebagai berikut: (1) Mengembangkan pemahaman tentang diri sendiri. (2) Memberikan gambaran yang tepat tentang konsep waktu, ruang, dan masyarakat. (3) Membuat masyarakat mampu mengevaluasi nilai-nilai dan hasil yang telah dicapai oleh generasinya. (4) Mengajarkan toleransi. (5) Menanamkan sikap intelektual. (6) Memperluas cakrawala intelektualitas. (7) Mengajarkan prinsip-prinsip moral. (8) Menanamkan orientasi ke masa depan. (9) Memberikan pelatihan mental. (10) Melatih siswa menangani isu-isu kontroversial. (11) Membantu mencarikan jalan keluar bagi berbagai masalah sosial dan perseorangan. (12) Memperkokoh rasa nasionalisme. (13) Mengembangkan pemahaman internasional. (14) Mengembangkan keterampilan-keterampilan yang berguna (Anis, 2013: 157-158).

Ketika sejarah diajarkan di SMA maka sasarannya menurut Kochhar, yaitu : (1) Memberikan pemahaman tentang tahap-tahap perkembangan masyarakat Indonesia dari abad ke abad. (2) Menumbuhkan penghargaan terhadap berbagai komponen budaya Indonesia dan bangga terhadap hasil yang telah dicapai oleh masyarakat Indonesia di berbagai wilayah. (3) Menumbuhkan pemahaman kritis tentang masa lalu, sehingga para siswa dapat terbebas dari prasangka yang irasional dan fanatik, pikiran sempit dan komunalisme, dan mencerahkannya dengan pemikiran ilmiah dan berorientasi ke masa 
depan. (4) Mengembangkan penghargaan terhadap kebudayaan Indonesia yang campur baur, kekayaan dan keragamannya, serta proses perkembangan yang dilaluinya, yaitu proses perubahan internal dalam kebudayaan Indonesia, interaksinya dengan kebudayaan lain, dan pengaruh kebudayaan. (5) Mengembangkan kemampuan untuk mengkaji masalahmasalah kontemporer masyarakat Indonesia dalam persfektif sejarahnya. (6) Memajukan studi tentang sejarah perkembangan Indonesia dan kaitannya dengan sejarah perkembangan peradaban manusia secara keseluruhan. (7) Mengembangkan pemahaman tentang proses perubahan sehingga pemahaman para siswa tentang proses perubahan yang terjadi dewasa ini semakin dalam, dan penghargaan terhadap aspirasi untuk melakukan perubahan guna menciptakan ketertiban sosial tertanam. (8) Mengembangkan kesadaran tentang pentingnya kerja pemeliharaan monumen-monumen sejarah dan berpartisipasi aktif di dalamnya (Anis, 2013: 158-159).

Mempelajari sejarah bukan sekedar hapalan atau hanya sekedar cerita tentang suatu peristiwa besar yang kemudian dilupakan dan tanpa memperoleh pemahaman sedikitpun. Peristiwa sejarah pasti mengandung nilai. Nilai pembelajaran sejarah apa yang kita peroleh dapat dipergunakan pendapat Kochhar di bawah ini: (1) Nilai Keilmuan, sejarah memberikan pelatihan mental yang sangat bagus. (2) Nilai Informatif, sejarah merupakan pusat informasi yang lengkap dan menyediakan panduan untuk menemukan jalan keluar dari semua masalah yanng dihadapi manusia. (3) Nilai Pendidikan, salah satu alasan terbaik untuk mengajarkan sejarah kepada anak-anak adalah nilai pendidikan yang terkandung di dalamnya. (4) Nilai Etika, sejarah dianggap sebagai bagian yang sangat penting dalam kurikulum sekolah, terutama dalam hal pembelajaran moralitas. (5) Nilai Budaya, sejarah dapat menjadi instrumen yang sangat efektif untuk membuat pikiran manusia lebih berbudaya. (6) Nilai Politik, sejarah juga membantu perpolitikan di negeri kita. (7) Nilai Nasionalisme, sebagai instrumen penggugah rasa cinta tanah air dalam pikiran anak-anak. (8) Nilai Internasional, sejarah sangat berharga bagi pengembangan akar internasionalisme yang rasional. (9) Nilai Kerja, sejarah memiliki nilai kerja. Berbagai pekerjaan terbuka bagi mereka yang menjadi sejarawan berkualitas. (10) Nilai Kependidikan, sejarah tidak hanya membantu para siswa dari berbagai umur dan kemampuan untuk menemukan posisi mereka di masa sekarang dengan cara menciptakan 
"hubungan yang menentramkan" dengan masa lampau, tetapi juga secara tidak langsung mengandung filsafat tentang asal-usul yang bermakna di masa lalu dan tujuan yang bermakna di masa depan, yang menjadi alasan bagi kerja keras manusia di masa sekarang (Anis, 2013: 159-160).

\section{PENGARUH MODERNISASI TERHADAP PENDIDIKAN}

Sebagai salah satu proses budaya, pendidikan dapat meningkatkan harkat dan martabat manusia yang berlangsung sepanjang hidup. Pendidikan juga berkembang sesuai dengan peradaban dan sekaligus berperan dalam pembentukan peradaban manusia sehingga pendidikan harus didesain mengikuti irama perubahan peradaban. Faktor pengembangan teknologi informasi dan komunikasi serta munculnya hubungan pasar di bidang pendidikan yang terkait dengan implementasi praktis dari ide dan konsep pembentukan sistem pendidikan modernisasi. Sebuah hal penting dari sistem pendidikan modern dan proses pembentukannya adalah globalisasi, yaitu karakter dunia dengan proses yang mendalam dan melekat. Hal ini merupakan manifestasi dari proses integrasi dunia modern dan interaksi intens antara negara-negara di berbagai bi- dang kehidupan masyarakat.

Mengenai pentingnya peranan pendidikan dalam proses modernisasi juga dikemukakan oleh C. Arnold Anderson dalam tulisannya mengenai modernisasi pendidikan (Weiner, 1981:16). Modernisasi hanya dapat dicapai dengan memperbaharui dan meluaskan pendidikan. Oleh sebab itu pemimpin negara yang sedang berkembang sangat mengutamakan pendidikan bagi proses modernisasi. Proses modernisasi menuntut perubahan dan perkembangan masyarakat secara cepat. Hal tersebut memerlukan penyesuaian pengetahuan, keterampilan, nilai-nilai dan sikap tertentu dari masyarakat. Yang berarti bahwa pendidikan dalam pembangunan dituntut untuk mengemban tugas yang semakin kompleks dan luas. Di Indonesia misalnya pendidikan juga dituntut untuk menstimulir masyarakat guna menjaga kelestarian hutan, mengikuti program keluarga berencana, mempertinggi kegemaran menabung di tabanas, dan sebagainya.

Dalam proses modernisasi, pendidikan memegang peranan cukup besar. Melalui pendidikan diharapkan pengembangan pengetahuan keterampilan dan nilai-nilai serta sikap-sikap yang dibutuhkan dalam proses modernisasi dapat ditransformasikan secara 
meluas di kalangan masyarakat baik melalui pendidikan formal informal maupun nonformal.

Dengan demikian pengaruh modernisasi memegang peran penting sebagai usaha pembangunan suatu bangsa Pendidikan, yaitu:

1. Mengembangkan nilai-nilai dan sikap yang dianggap serasi Dan dibutuhkan oleh masyarakat dalam menghadapi perkembangan ilmu dan teknologi.

2. Pembentukan tenaga pembangunan yang ahli dan terampil serta meningkatkan produktivitas kualitas.

3. Membentuk pribadi-pribadi yang memiliki kepercayaan diri disiplin dan tanggung jawab serta menjadi warga negara yang baik.

\section{SIMPULAN}

Pendidikan dan modernisasi mempunyai hubungan yang saling mempengaruhi. Pendidikan menjadi sarana untuk mencapai modernisasi. Dengan pendidikan, proses modernisasi tersebut akan terbentuk dengan baik dan akan berdampak lagi ke pendidikan itu sendiri. Modernisasi juga akan mempengaruhi pendidikan. Karena dengan modernisasi, inovasi dan pembaharuan di bidang pendidikan akan di dapatkan. Terutama pada zaman sekarang, dimana modernisasi ini sangat berperan penting dalam pendidikan. Kedua hal tersebut menjadi sebuah siklus yang berkaitan dan berjalan terus menerus.

Ketika pendidikan dan modernisasi ini berjalan, tentunya di antara kedua hal tersebut ada pendidikan karakter yang harus ditanamkan ke manusia. Karena modernisasi tanpa karakter itu tidak akan bisa sempurna. Dalam pendidikan karakter sangat erat kaitannya dengan pendidikan sejarah. Karena pendidikan sejarah disini akan membentuk karakter manusia melalui pembelajarannya dan membentuk manusia yang berbakti kepada Negara pada umumnya.

\section{REFERENSI}

Anis, M. Z. A. (2013). ILMU SEJARAH SEBAGAI SUMBER PEMBELAJARAN IPS. Mewacanakan Pendidikan IPS, 149.

Departemen P dan K. Badan Pengembangan Pendidikan. 1974. Pendidikan Non-formal di 
Indonesia.

ER, N. D. (1991). Memahami Peranan Pendidikan dalam Proses Modernisasi. Jurnal Cakrawala Pendidikan, 1(1).

Matondang, A. (2019). Dampak Modernisasi Terhadap Kehidupan Sosial Masyarakat. Wahana Inovasi: Jurnal Penelitian Dan Pengabdian Masyarakat UISU, 8(2), 188-194.

Non-Reg, N. M. E. E., Non-Reg, N. H. E. E., \& Uyun, A. S. PENGERTIAN PENDIDIKAN.

Rougers, Everett M. 1971. Modernization Aming Peasants.Michigan State University.

Tampubolon Hotner. 2017. Modernisasi Pendidikan Suatu Perspektif. Jakarta: Papas Sinar Sinanti

Zaenal Arifin Anis, M. (2014). Sejarah, Pendidikan Sejarah, dan Pendidikan Karakter Dialog yang Tidak Pernah Dituntaskan. 